Article

\title{
In Vitro Antibacterial Potential of Salix babylonica Extract against Bacteria that Affect Oncorhynchus mykiss and Oreochromis spp.
}

\author{
Lenin Rangel-López ${ }^{1,2}$, Adrian Zaragoza-Bastida ${ }^{1, * D}$, Benjamín Valladares-Carranza ${ }^{3}$, \\ Armando Peláez-Acero ${ }^{1}$, Carolina G. Sosa-Gutiérrez ${ }^{1}$, Helal F. Hetta ${ }^{4}$ (D), \\ Gaber El-Saber Batiha ${ }^{5}\left(\mathbb{D}\right.$, Ali Alqahtani ${ }^{6}(\mathbb{D})$ and Nallely Rivero-Perez ${ }^{1, *(D)}$
}

1 Instituto de Ciencias Agropecuarias, Área Académica de Medicina Veterinariay Zootecnia, Universidad Autónoma del Estado de Hidalgo, Rancho Universitario Av. Universidad km 1, EX-Hda de Aquetzalpa, Tulancingo, Hidalgo 43600, Mexico; ralolenin@gmail.com (L.R.-L.); pelaeza@uaeh.edu.mx (A.P.-A.); carolina_sosa@uaeh.edu.mx (C.G.S.-G.)

2 División Académica en Ciencias Agropecuarias, Universidad Juárez Autónoma de Tabasco, carretera Villahermosa-Teapa Kilómetro 25+2 Rancheria la Huasteca 2da sección, Villahermosa 86298, Mexico

3 Facultad de Medicina Veterinaria y Zootecnia Universidad Autónoma del Estado de México, El Cerrillo Piedras Blancas, Toluca 50295, Mexico; benvac2004@yahoo.com.mx

4 Department of Medical Microbiology and Immunology, Faculty of Medicine, Assiut University, Assiut 71515, Egypt; helal.hetta@uc.edu

5 Department of Pharmacology and Therapeutics, Faculty of Veterinary Medicine, Damanhour University, Damanhour 22511, Egypt; gaberbatiha@gmail.com

6 Department of Pharmacology, College of Pharmacy, King Khalid University, Guraiger, Abha 62529, Saudi Arabia; amsfr@kku.edu.sa

* Correspondence: adrian_zaragoza@uaeh.edu.mx (A.Z.-B.); nallely_rivero@uaeh.edu.mx (N.R.-P.)

Received: 16 June 2020; Accepted: 29 July 2020; Published: 3 August 2020

Simple Summary: Aquaculture development is limited by several diseases associated with bacteria that have developed resistance to antibiotics. In this context, new treatment alternatives are necessary. The aim of the present study was to evaluate the in vitro antibacterial effects of Salix babylonica hydro-alcoholic extract against some bacteria that affect rainbow trout (Oncorhynchus mykiss) and tilapia (Oreochromis spp.). The results indicate that Salix babylonica hydro-alcoholic extract has an antibacterial effect and could be an alternative treatment in diseases caused by microorganisms resistant to drugs in aquaculture.

\begin{abstract}
Aquaculture development is limited by bacteria associated with several diseases; antibiotics are used for the treatment of these affections, but bacteria have developed resistance to these drugs. It is important to develop effective treatments that allow the production of antibiotic-free food. The aim of the present study is to evaluate the in vitro antibacterial effects of Salix babylonica hydro-alcoholic extract (SbHE) against Aeromonas hydrophila, Listonella anguillarum, Edwarsiella tarda, and Streptococcus iniae, bacteria that affect Oncorhynchus mykiss and Oreochromis spp. production. SbHE was obtained through the maceration technique. Reference strains were used and their sensitivity to antibiotics was determined. Minimal inhibitory concentration (MIC) and minimal bactericidal concentration (MBC) of SbHE were determined. Results showed that three of four evaluated bacteria were multidrug resistant, except $S$. iniae. SbHE showed antibacterial activity against all bacteria. Results indicate an MIC of 1.56 to $25 \mathrm{mg} / \mathrm{mL}$ and an MBC of 3.12 to $100 \mathrm{mg} / \mathrm{mL}$. The greatest inhibitory activity occurred against L. anguillarum obtaining a MIC of $1.56 \mathrm{mg} / \mathrm{mL}$ and an MBC of $3.12 \mathrm{mg} / \mathrm{mL}$. Results indicate that SbHE has bactericidal activity against $A$. hydrophila, L. anguilalurm, and $S$. iniae as well as bacteriostatic activity against $E$. tarda and could be an alternative treatment against these bacteria.
\end{abstract}


Keywords: Salix babylonica extract; in vitro; antibacterial activity; Oncorhynchus mykiss; Oreochromis spp.

\section{Introduction}

Aquaculture is an agropecuary activity with growth potential primarily within the commercial alimentary industry, with a world production of 80 million tons annually [1]. In 2017, Mexico produced approximately 404 thousand tons of aquaculture products. Of these, the highest yielding species were tilapia and trout [2].

It has been observed that aquatic organisms are more susceptible to infectious agents, when density is increased, and water as well as food quality is decreased [3]. Infectious diseases, mainly those associated with bacteria, represent a great challenge in fish farming, since they affect fish growth, increase mortalities, and require treatment, which generate significant economic losses [4].

Vaccines, immunostimulants, chemotherapeutics, and antibiotics have been used for many years for the control and treatment of bacterial diseases. The use of chemotherapeutics and antibiotics are undesirable since they accumulate in the muscles, contaminate aquatic environments, stimulate the development of bacterial resistance, and increase production costs. As such, their use has been restricted in some countries [5-8]. Commonly used antibiotics in the treatment of bacterial infections in aquaculture are enrofloxacin, florfenicol, oxytetracycline, chlortetracycline, ciprofloxacin, norfloxacin, oxolinic acid, perfloxacin, sulfamethazine, gentamicin, and tiamulin $[9,10]$.

Some bacteria that affect aquaculture is Aeromonas hydrophila, a Gram-negative bacterium, with a cosmopolitan distribution, that thrives in freshwater as well as marine environments. A. hydrophila causes skin ulcerations, hemorrhagic septicemia (red sore disease, red rot disease, and squamous protrusion disease). Multi-drug resistance of this bacterium to antibiotics has been previously reported [11-13].

Listonella anguillarum is a Gram-negative bacterium that affects rainbow trout (Oncorhynchus mykiss) which causes erythema around the fins and mouth, lethargy, appetite loss, skin color change, ulcers on the integument, injuries in abdominal muscles, liver, gills, spleen, and kidneys [14].

On the other hand, Edwarsiella tarda, a Gram-negative bacterium that affects tilapia (Oreochromis spp.) causes capillary hyperemia, exudation, focal petechial hemorrhages, leukocytosis, and hemorrhagic septicemia. Furthermore, it also produces lesions in the intestine and skin as well as exophthalmia [15]. Finally, Streptococcus iniae a Gram-positive bacterium that affects Oreochromis spp., causes meningoencephalitis, lethargy, back stiffness, erratic behavior in swimming, and death [16]. Antibiotic resistance to multidrug treatments has been reported for both pathogens [17].

Multidrug resistance (antibacterials) in aquaculture systems requires that alternative therapies be explored for the treatment of diseases caused by these agents. Among these alternatives, the use of plant extracts has been proposed; due to their content of secondary compounds such as alkaloids, terpenes, tannins, saponins, glycosides, and flavonoids, they have shown antibacterial activity in studies in vitro and in vivo in fish and shellfish [18]. On the other hand, it has been demonstrated that plant extracts are safer, more environmentally friendly, inexpensive, accessible, and easier to prepare than commercial antibiotics. Most importantly, they present fewer side effects over treated organisms, and are overall safer $[19,20]$.

The antibacterial activity of plant extracts has been demonstrated against some bacterial strains of significance in aquaculture production. Tkachenko et al. determined the in vitro antibacterial activity of ethanolic extract from leaves of Ficus spp. using the disk diffusion method, against A. hydrophila, isolated from O. mykiss [12]. Their results indicate that the extract presents an intermediate inhibitory activity (10-12 mm of inhibition halos) on the growth of this bacterium. Boran et al. evaluated the in vitro antibacterial activity of Green tea (Camellia sinensis) with the disk diffusion method against L. anguillarum [21]. They demonstrated the susceptibility of this bacterium to the extract, with an inhibition diameter of $18 \mathrm{~mm}$. 
Baba et al. infected tilapias with E. tarda, previously supplemented with Citrus limon essential oil at a concentration of $0.5 \%$ in commercial food [22], and survival rates of $63.33 \%$ after 20 days were observed. Gütepe et al. fed tilapias with Thymus vulgaris, Rosmarinus officinalis, and Trigonella foenum extracts throughout 45 days [23]. They were then infected with S. iniae, resulting in a survival rate of $88 \%$ in fish fed T. vulgaris extract.

Salix babylonica, commonly known as weeping willow, is a tree that belongs to Salicaceae family, their leaves contain flavonoids, terpenoids, lignans, and phenolic compounds [24]. This species has been evaluated by different authors to determine its antibacterial activity against some bacteria of importance in human and animal medicine. In a study conducted in 2015 by Popova and Kaleva, weeping willow leaves were collected during different seasons, to evaluate its antibacterial activity against Escherichia coli, Salmonella enterica, and Staphylococcus aureus. They observed the best results occurred with leaves collected in June. These induced an antibacterial activity less than $100 \mathrm{mg} / \mathrm{mL}$ [25].

In this regard, Ali and Aboud [26] evaluated the methanolic extract of S. babylonica and its hot and cold water infusions. They determined that Enterobacter spp., Klebsiella spp., A. hydrophila, and Shigella dysenteriae, showed resistance to treatments evaluated independently of the extraction method. The methanolic extract inhibited the growth of Pseudomonas aeruginosa $(50 \mathrm{mg} / \mathrm{mL})$, E. coli $(100 \mathrm{mg} / \mathrm{mL})$, and S. aureus $(50 \mathrm{mg} / \mathrm{mL})$. The hot water infusion inhibited growth of these bacteria at a concentration of $100 \mathrm{mg} / \mathrm{mL}$. González-Alamilla et al. [27] evaluated the hydroalcoholic extract of S. babylonica against E. coli, Listeria monocytogenes, and S. aureus obtaining a minimal inhibitory concentration (MIC) of $100 \mathrm{mg} / \mathrm{mL}, 50 \mathrm{mg} / \mathrm{mL}$, and $25 \mathrm{mg} / \mathrm{mL}$, respectively. In 2020 González-Alamilla et al. evaluated the methanolic extract of S. babylonica against E. coli, Salmonella typhi, Salmonella choleraesuis, and P. aeruginosa and determined a MIC of $100 \mathrm{mg} / \mathrm{mL} ; 25 \mathrm{mg} / \mathrm{mL}$ for S. aureus and L. monocytogenes and a MIC of $12.5 \mathrm{mg} / \mathrm{mL}$ over Bacillus subtillis [28].

In accordance with the aforementioned, the aim of the present study was to evaluate the antibacterial effect of Salix babylonica hydro-alcoholic extract (SbHE) against A. hydrophila, L. anguilalurm, E. tarda, and S. iniae, bacteria that affect rainbow trout (Oncorhynchus mykiss) and tilapia (Oreochromis spp.) production.

\section{Materials and Methods}

\subsection{Plant Material}

Weeping willow (Salix babylonica) leaves were collected in the municipality of Tulancingo de Bravo,

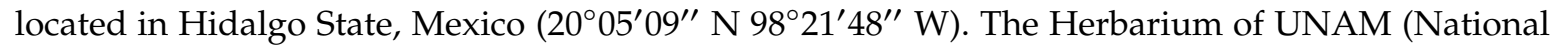
Autonomous University of Mexico) was consulted and the plant was verified as Salix babylonica L. (IBUNAM: MEXU: 9744).

\subsection{Hydroalcoholic Extract Obtention}

SbHE was prepared following the methodology described by González-Alamilla et al. [27]. First, $1000 \mathrm{~g}$ of weeping willow leaves (Salix babylonica) were collected, washed, and dried in shade at room temperature. Then, $250 \mathrm{~g}$ of dried leaves obtained were macerated in $1000 \mathrm{~mL}$ of hydroalcoholic solution (30\% methanol and $70 \%$ water) over $48 \mathrm{~h}$ at room temperature and in light absence. Subsequently, the mixture was filtered with filter paper (Whatman ${ }^{\circledR} 42$, Darmstadt, Germany), and finally the extract was concentrated under reduced pressure in a rotary evaporator (Büchi R-300, Flawil, Switzerland).

\subsection{Bacterial Strains and Culture Conditions}

The strains used were Aeromonas hydrophila CAIM347, Listonella anguillarum CAIM 763, Streptococcus iniae CAIM527, and Edwardsiella tarda CAIM 1875. These were obtained from the Collection of Microorganisms of Aquatic Importance (CAIM) of the Center for Research in Food and Development of Mazatlán, Sinaloa, Mexico (CIAD). Strains were reactivated in Trypticase Soy Agar (DIBICO ${ }^{\circledR}$, Mexico City, Mexico) and incubated at $30^{\circ} \mathrm{C}$ and $37^{\circ} \mathrm{C}$ (only S. iniae) for $24 \mathrm{~h}$. After incubation a colony was inoculated in nutritive broth (Becton Dickinson and Difco Company, Chicago, IL, USA) and incubated at $30^{\circ} \mathrm{C}$ and $37^{\circ} \mathrm{C}$ for $24 \mathrm{~h}$. 


\subsection{Test of Antibiotic Sensitivity}

Antibiotic sensitivity was determined using the disk diffusion method in Muller-Hinton agar (DIBICO ${ }^{\circledR}$ Mexico City, Mexico). Following the methodology described by the Clinical and Laboratory Standards Institute (CLSI) [29], $100 \mu \mathrm{L}$ previously adjusted to a $0.5 \mathrm{McFarland}$ standard (Remel, R20421, Lenexa, KS, USA) of each bacterial strain were inoculated and evenly distributed on the plate. After $15 \mathrm{~min}$, multidiscs (PT-35, Mexico City, Mexico) were placed on the plate and incubated at $30^{\circ} \mathrm{C}$ and $37^{\circ} \mathrm{C}$ (only S. iniae) for $24 \mathrm{~h}$. After incubation completion time, the inhibition halos were measured and were compared with the measures established by the CLSI. The antibacterial agents used were cephalotin $(30 \mu \mathrm{g})$, cefotaxime $(30 \mu \mathrm{g})$, ciprofloxacin $(5 \mu \mathrm{g})$, chloramphenicol $(30 \mu \mathrm{g})$, nitrofurantoin $(300 \mu \mathrm{g})$, ampicillin $(10 \mu \mathrm{g})$, carbenicillin $(100 \mu \mathrm{g})$, gentamicin $(10 \mu \mathrm{g})$, netilmicin $(30 \mu \mathrm{g})$, norfloxacin $(10 \mu \mathrm{g})$, sulfamethoxazole/trimethoprim $(25 \mu \mathrm{g})$, and amikacin $(30 \mu \mathrm{g})$.

\subsection{Test of Antibacterial Activity}

For determined SbHE antibacterial activity, the minimal inhibitory concentration (MIC) and the minimal bactericidal concentration (MBC) were obtained, in accordance with the CLSI guidelines [29]. To determine the MIC, microdilution in a plate was used. The concentrations evaluated of SbHE were $1.56,3.12,6.25,12.50,25,50,100$, and $200 \mathrm{mg} / \mathrm{mL}$; as a positive control we employed Kanamycin (0.03-4.0 $\mu \mathrm{g} / \mathrm{mL}$, AppliChem 4k10421, Darmstadt, Germany) and for the negative control we used nutritive broth (Becton Dickinson and Difco Company, Chicago, IL, USA). Treatments were evaluated in triplicate.

In a 96-well plate, $100 \mu \mathrm{L}$ of SbHE concentrations were added, along with $10 \mu \mathrm{L}$ of a bacterial cell suspension previously adjusted to a $0.5 \mathrm{McFarland}$ standard. The plates were incubated at $30{ }^{\circ} \mathrm{C}$ for A. hydrophila, L. anguillarum, and E. tarda and at $37^{\circ} \mathrm{C}$ for S. iniae, for $24 \mathrm{~h}$. Once the incubation period elapsed, $20 \mu \mathrm{L}$ of a $0.04 \%(\mathrm{w} / \mathrm{v}) \mathrm{p}$-iodonitrotetrazolium (Sigma-Aldrich 18377 , St. Louis, MO, USA) solution were added into each well and incubated for $30 \mathrm{~min}$ at $30^{\circ} \mathrm{C}$ and $37^{\circ} \mathrm{C}$. The MIC was determined by the concentration at which the solution turned pink [30].

To determine the minimal bactericidal concentration (MBC) prior to addition of p-iodonitrotetrazolium, $5 \mu \mathrm{L}$ from each well were inoculated in Müller-Hinton agar (DIBICO ${ }^{\circledR}$ Mexico City, Mexico) and incubated at $30^{\circ} \mathrm{C}$ and $37^{\circ} \mathrm{C}$ (S. iniae) for $24 \mathrm{~h}$. The MBC was determined by the concentration at which no visible growth of the bacteria occurred [31].

\subsection{Statistical Analysis}

Data were obtained from the disk diffusion method, and MIC and MBC were normalized and analyzed using a variance analysis (ANOVA) to determine significant statistical differences between treatments. The difference between means was compared with Tukey's test $(p<0.05)$ using SAS version 9.0 (SAS Institute, NC, USA)

\section{Results}

\subsection{Test of Antibiotic Sensitivity}

Results of antibiotic sensitivity showed that three of four bacterial strains (A. hydrophila, L. anguillarum and E. tarda) were resistant to at least three antibiotics. A. hydrophila and E. tarda were resistant to cephalotin, ampicillin, and carbenicillin. L. anguillarum was resistant to cephalotin, ampicillin, and amikacin and S. iniae was only resistant to ciprofloxacin (Table 1). 
Table 1. Results of inhibition halos ( $\mathrm{mm}$ ) and antibiotic sensitivity of A. hydrophila, L. anguillarum, E. tarda, and S. iniae.

\begin{tabular}{ccccc}
\hline Antibiotic & A. hydrophila & L. anguillarum & E. tarda & S. iniae \\
\hline Cephalotin & $14(\mathrm{R})$ & $14(\mathrm{R})$ & $14(\mathrm{R})$ & $35(\mathrm{~S})$ \\
Cefotaxime & $30(\mathrm{~S})$ & $26(\mathrm{~S})$ & $30(\mathrm{~S})$ & $30(\mathrm{~S})$ \\
Ciprofloxacin & $25(\mathrm{~S})$ & $25(\mathrm{~S})$ & $30(\mathrm{~S})$ & $15(\mathrm{R})$ \\
Cloramphenicol & $25(\mathrm{~S})$ & $20(\mathrm{~S})$ & $20(\mathrm{~S})$ & $20(\mathrm{~S})$ \\
Nitrofurantoin & $25(\mathrm{~S})$ & $25(\mathrm{~S})$ & $25(\mathrm{~S})$ & $20(\mathrm{~S})$ \\
Ampicillin & $6(\mathrm{R})$ & $6(\mathrm{R})$ & $11(\mathrm{R})$ & $30(\mathrm{~S})$ \\
Carbenicillin & $6(\mathrm{R})$ & $17(\mathrm{~S})$ & $18(\mathrm{R})$ & $30(\mathrm{~S})$ \\
Gentamicin & $20(\mathrm{~S})$ & $20(\mathrm{~S})$ & $20(\mathrm{~S})$ & $20(\mathrm{~S})$ \\
Netilmicin & $20(\mathrm{~S})$ & $15(\mathrm{~S})$ & $22(\mathrm{~S})$ & $20(\mathrm{~S})$ \\
Norfloxacin & $20(\mathrm{~S})$ & $20(\mathrm{~S})$ & $20(\mathrm{~S})$ & $25(\mathrm{~S})$ \\
Amikacin & $22(\mathrm{~S})$ & $20(\mathrm{~S})$ & $18(\mathrm{~S})$ & $20(\mathrm{~S})$ \\
Sulfamethoxazole/Trimethoprim & $20(\mathrm{~S})$ & $6(\mathrm{R})$ & $20(\mathrm{~S})$ & $20(\mathrm{~S})$ \\
\hline
\end{tabular}

S: sensitive, R: resistant.

\subsection{Test of Antibacterial Activity}

The results showed the extract has the capacity to inhibit the growth of the strains evaluated. Nevertheless, significant statistical differences $(p=0.0001)$ were observed among them. The SbHE presented more effective inhibitory activity against $L$. anguillarum $(1.56 \mathrm{mg} / \mathrm{mL})$, followed by E. tarda $(3.12 \mathrm{mg} / \mathrm{mL})$, and finally A. hydrophila and S. iniae $(25 \mathrm{mg} / \mathrm{mL})$ (Table 2).

Table 2. Minimal inhibitory concentration and minimal bactericidal concentration of hydroalcoholic extract from Salix babylonica against evaluated bacteria.

\begin{tabular}{|c|c|c|c|c|c|c|}
\hline \multirow{2}{*}{ Bacteria } & \multicolumn{2}{|c|}{$\begin{array}{l}\text { Minimal Inhibitory } \\
\text { Concentration }\end{array}$} & \multirow{2}{*}{$\begin{array}{l}\text { Negative } \\
\text { Control }\end{array}$} & \multicolumn{2}{|c|}{$\begin{array}{l}\text { Minimal Bactericidal } \\
\text { Concentration }\end{array}$} & \multirow{2}{*}{$\begin{array}{l}\text { Negative } \\
\text { Control }\end{array}$} \\
\hline & $\begin{array}{c}\text { SbHE } \\
(\mathrm{mg} / \mathrm{mL})\end{array}$ & $\begin{array}{l}\text { Positive Control } \\
(\mu \mathrm{g} / \mathrm{mL})\end{array}$ & & $\begin{array}{c}\text { SbHE } \\
(\mathrm{mg} / \mathrm{mL})\end{array}$ & $\begin{array}{l}\text { Positive Control } \\
(\mu \mathrm{g} / \mathrm{mL})\end{array}$ & \\
\hline A. hydrophila & $25^{c}$ & $2^{b}$ & NA & $100^{c}$ & $4^{c}$ & NA \\
\hline L. anguillarum & $1.56^{\mathrm{a}}$ & $0.5^{\mathrm{a}}$ & NA & $3.12^{\mathrm{a}}$ & $0.5^{\mathrm{a}}$ & NA \\
\hline E. tarda & $3.12^{b}$ & $0.5^{\mathrm{a}}$ & NA & $25^{b}$ & $0.5^{\mathrm{a}}$ & NA \\
\hline S. iniae & $25^{c}$ & $0.5^{\mathrm{a}}$ & NA & $25^{b}$ & $1^{b}$ & NA \\
\hline$p$-Value & 0.0001 & & & 0.0001 & & \\
\hline
\end{tabular}

SbHE = Salix babylonica hydroalcoholic extract. NA = No activity. ${ }^{a, b, c}$ Different literals in the columns indicate significant statistical differences $(p \leq 0.05)$.

On the other hand, results of minimal bactericidal concentration of SbHE indicated that this extract has bactericidal effects against all evaluated bacteria $(p=0.0001)$. Greater bactericidal activity was observed against L. anguillarum $(3.12 \mathrm{mg} / \mathrm{mL})$ followed by E. tarda and S. iniae $(25 \mathrm{mg} / \mathrm{mL})$; of these, A. hydrophila (100 mg/mL) was the least susceptible to SbHE (Table 2).

\section{Discussion}

For many years antibacterials have been used indiscriminately in aquaculture which has led to the emergence of bacteria resistant or multiresistant to these drugs, a problem that has stimulated the search for functional, innocuous alternative, with low environmental impact. Plants and their derivatives comply with these characteristics and have been shown to induce antibacterial activity during in vitro and in vivo studies; as such, potentially leading to the development of an alternative for use in fisheries units [32].

As with other livestock activities fish farming is also affected by the presence of infectious diseases, mainly those associated with bacteria. A. hydrophila, L. anguillarum, E. tarda, and S. iniae have been linked with mortality ranges of $50 \%$ to $100 \%$ in aquaculture production systems of $O$. mykiss and 
Oreochromis spp. Clinical signs of infected individuals may occur or be asymptomatic and lead to sudden death [33-35].

In the present study, an antibiotic sensitivity test was performed with reference strains of A. hydrophila, L. anguillarum, E. tarda, and S. iniae. Results indicated that A. hydrophila is resistant to at least two antibiotics groups (cephalosporin: cephalotin and penicillin: ampicillin and carbenicillin). According to López-Pueyo et al. [36], this strain can be classified as multidrug resistant, since it presents resistance to more than one group of antimicrobials. The bacteria is of clinical importance and has the ability to generate epidemic outbreaks where it is present.

Wamala et al. [37] determined the sensitivity to antibiotics of bacteria belonging to the same genus (Aeromonas spp.) and observed resistance to ampicillin, corroborating the results of the present study. Meanwhile, Negrete et al. [38] identified different bacteria isolated from kidneys of Carassius auratus, including A. hydrophila, which was classified as multidrug resistant (resistant to cephalotin, tetracycline, nefilmezine, ampicillin, carbenicillin, and kanamycin), further supporting results of the present investigation in which this bacteria was resistant to cephalothin, ampicillin, and carbenicillin.

On the other hand, L. anguillarum showed resistance to cephalotin, ampicillin, and amikacin. According to the criteria outlined by Lopez-Pueyo et al. [36], this bacterium can be classified as a multidrug resistant strain. In a similar study carried out by Vaseeharan and Ramasamy, who isolated L. anguillarum from Penaeus monodon [39], resistance to ampicillin, chlortetracycline, streptomycin, and penicillin was reported, further reinforcing the resistance to ampicillin reported in the present study.

E. tarda showed the same resistance pattern as A. hydrophila (resistant to cephalothin, ampicillin, and carbenicillin). Nikapitiya et al. [40] carried out tests for sensitivity to antibiotics with bacteria isolated from Danio rerio, including E. tarda. That research reported that this bacterium was resistant to beta-lactams (penicillin, amoxicillin), further supporting our results.

S. iniae was a strain sensitive to most of the antibiotics used in the present study. Nevertheless, it was the only bacterium resistant to ciprofloxacin, coinciding with the results of Mukwabi et al., who isolated different bacteria from aquaculture production systems in Kenya [17]. S. iniae was among the bacteria isolated in that study and showed resistance to ciprofloxacin.

The strains used for the antibacterial evaluation of SbHE showed different degrees of sensitivity to antibiotics, most of them being multi-resistant to antibacterial agents. The evaluation of SbHE antibacterial activity against bacteria that affect aquaculture production of $O$. mykiss, showed that the extract can inhibit the growth of $A$. hydrophila (MIC of $25 \mathrm{mg} / \mathrm{mL}$ ). Wei et al. evaluated in seeds and flowers the methanolic extract of Michelia champaca and determined that the concentration at which growth of A. hydrophila was inhibited [41] was at 31.3 and $15.6 \mathrm{mg} / \mathrm{mL}$, respectively. These concentrations are similar to the ones obtained in the present study.

In this sense, SbHE inhibited growth of L. anguillarum at a concentration of $1.56 \mathrm{mg} / \mathrm{mL}$. Bulfon et al. [42] analyzed 15 ethanolic extracts against L. anguillarum, and reported that only Lavandula officinalis and Origanum vulgare inhibited the growth of this bacteria at a concentration of $2.1 \mathrm{mg} / \mathrm{mL}$, a greater concentration than that reported in the present study which could be due to the type and concentration of secondary metabolites present in S. babylonica leaves and the kind of extract used in both studies.

Determination of MIC of SbHE on bacteria that affect the production of Oreochromis spp., allowed us to determine that the growth of $S$. iniae was inhibited at $25 \mathrm{mg} / \mathrm{mL}$. Abutbul et al. [43] evaluated ethanol, methanol, ethyl acetate, and methanol/ethyl acetate extracts from Rosmarinus officinalis against S. iniae, using the disk diffusion technique. The best results obtained were those treated with the ethyl acetate extract that presented an inhibition halo of $37.5 \mathrm{~mm} / \mathrm{mg}$. Nevertheless, these results are not totally comparable since the technique used was different from that used in the present experiment.

Regarding E. tarda, growth was inhibited by SbHE at a concentration of $3.12 \mathrm{mg} / \mathrm{mL}$. In 2009 Lee and Najiah obtained a MIC of $15.6 \mathrm{mg} / \mathrm{mL}$ with Citrus microcarpa extract using an American Type Culture Collection (ATCC) strain of E. tarda and 7.8-31.3 mg/mL over field strains [44]. The MIC of SbHE was lower even when comparing our MIC with that obtained against $E$. tarda field strains. 
The minimal bactericidal concentration of SbHE against bacteria that affects O. mykiss and Oreochromis spp. production showed that SbHE has bactericidal effects against L. anguillarum $(3.12 \mathrm{mg} / \mathrm{mL})$, E. tarda and S. iniae $(25 \mathrm{mg} / \mathrm{mL})$, and A. hydrophila $(100 \mathrm{mg} / \mathrm{mL})$. Roomiani et al. [45] evaluated methanolic extracts of Rosmarinus officinalis, Anethum graveolens, Zataria multiflora, and Eucalyptus globulus against S. iniae, obtaining an MBC of 15.6 to $500 \mu \mathrm{g} / \mathrm{mL}$, lower concentrations than those obtained in the present study. Nevertheless, the plants and kind of extracts differed, therefore the kind of compounds present and the activity of each one changed [46]. Currently the number of studies in which the MBC of plant extracts is determined is lacking, which limits the discussion of our results.

Calculations of the MBC/MIC ratio indicated that SbHE has bacteriostatic activity against E. tarda and bactericidal activity against A. hydrophila, L. anguillarum, and S. iniae. According to Djihane et al. [47], when the MBC/MIC ratio is greater than four the effect is bacteriostatic and when it is less than or equal to four the effect is bactericidal. When analyzing the results of the experiment performed by Roomiani et al., it was observed that the extracts of Rosmarinus officinalis, Anethum graveolens, Zataria multiflora, and Eucalyptus globulus have a bactericidal effect against S. iniae, corresponding with our results.

Some studies have established that the antibacterial activity of plant extracts is due to their content of secondary metabolites. Gligoric et al. analyzed different Salix extracts [48], finding that S. babylonica has phenolic compounds $(20.17 \mathrm{mg})$ and flavonoids $(3.13 \mathrm{mg})$. González-Alamilla et al. analyzed S. babylonica methanolic extract, and found the extract contains thymol $(0.5319 \mathrm{mg} / \mathrm{mL})$ and carvacrol $(0.4158 \mathrm{mg} / \mathrm{mL})$ [28].

Furthermore, Rivero-Pérez et al. [49] determined the partial chemical composition of S. babylonica hydroalcoholic extract, finding phenolic compounds, coumarins, lactans, sterols, triterpenes, flavonols, flavonoids, saponins, and floratanins, as well as linalol, thymol, and carvacrol, which were identified using gas chromatography. González-Alamilla et al. reported that the organic fraction of S. babylonica hydroalcoholic extract [27] contains the secondary metabolites with the highest antibacterial activity and determined that two flavonoids (luteolin and luteolin glucoside) are responsible for this activity.

Additionally, it has been reported in in vivo studies in sheep, goats, and rabbits that SbHE does not modify hematological parameters associated with the overall health status of animals under study. Nor does it kill Artemia salina exposed to the extract, at the doses and frequencies reported, so it could be inferred that the extract is nontoxic [49,50].

\section{Conclusions}

The present study showed that SbHE has bactericidal activity in vitro, against $A$. hydrophila, L. anguilalurm, and S. iniae and bacteriostatic activity against $E$. tarda, bacteria of significance in rainbow trout and tilapia production, used in the food industry. The greatest results obtained were those against L. anguillarum. Thus, it may be an alternative treatment against these bacteria commonly found in fisheries. To further explore the use of this alternative, however, it is necessary to carry out in vivo studies.

Author Contributions: Conceptualization and methodology, N.R.-P., L.R.-L., C.G.S.-G., and A.Z.-B.; validation and formal analysis, N.R.P., A.Z.-B., L.R.-L., and A.P.-A.; investigation and resources, N.R.-P. and A.Z.-B.; data curation, A.Z.-B., L.R.-L., and B.V.-C.; writing-original draft preparation, L.R.-L., H.F.H., and N.R.-P.; writing-review and editing, A.Z.-B., B.V.-C., A.A., and G.E.-S.B.; supervision, N.R.-P., and A.Z.-B.; project administration, N.R.-P. and A.Z.-B.; funding acquisition, N.R.-P., A.Z.-B., and A.P.-A. All authors have read and agreed to the published version of the manuscript.

Funding: This research did not receive any specific grant from funding agencies in the public, commercial, or not-for-profit sectors.

Acknowledgments: The authors would like to acknowledge the Universidad Autónoma del Estado de Hidalgo (UAEH) by for the support provided for carrying out the study in its facilities. This study formed part of the $\mathrm{PhD}$ thesis of Lenin Rangel Lopez (Doctorado en Ciencias Agropecurias, Universidad Autónoma del Estado de Hidalgo), under the direction of Adrian Zaragoza Bastida and Nallely Rivero Perez.

Conflicts of Interest: The authors declare no conflict of interest. 


\section{References}

1. FAO. El Estado Mundial de la Pesca y la Acuicultura 2018, Cumplir los Objetivos de Desarrollo Sostenible. Roma. Licencia: CC BY-NC-SA 3.0 IGO. Page 2 a 8. Available online: http://www.fao.org/3/i9540es/i9540es.pdf (accessed on 30 May 2020).

2. CONAPESCA. Anuario Estadístico de Acuacultura y Pesca. 2017. Available online: http://www.gob.mx/ conapesca/documentos/anuario-estadistico-de-acuacultura-y-pesca (accessed on 25 May 2020).

3. Terzi, E.; Corum, O.; Bilen, S.; Kenanoglu, O.N.; Uney, K. Pharmacokinetics of danofloxacin in rainbow trout after different routes of administration. Aquaculture 2020, 520, 734984. [CrossRef]

4. Farsani, M.N.; Hoseinifar, S.H.; Rashidian, G.; Farsani, H.G.; Ashouri, G.; Doan, H.V. Dietary effects of Coriandrum sativum extracto $\mathrm{n}$ growth performance, physiological and innate immune responses and resistance of rainbow trout (Oncorhynchus mykiss) against Yersinia ruckeri. Fish Shellfish Immunol. 2019, 91, 233-240. [CrossRef] [PubMed]

5. Penagos, G.; Barato, P.; Iregui, C. Sistema inmune y vacunación de peces. Acta Biol. Colomb. 2008, 14, 3-24. [CrossRef]

6. Caruso, D.; Lusiastuti, A.M.; Taukhid; Slembrouck, J.; Komarudin, O.; Legendre, M. Tradicional pharmacopeia in small scale freshwater fish farms in west Java, Indonesia: An ethnoveterinary approach. Aquaculture 2013, 416, 334-345. [CrossRef]

7. Acar, Ü.; Kesbiç, O.S.; Yimaz, S.; Gültepe, N.; Türker, A. Evaluation of the effects essential oil extracted from sweet orange peel (Citrus sinensis) on growth rate of tilapia (Oreochromis mossambicus) and posible disease resistance against Streptococcus iniae. Aquaculture 2015, 437, 282-286. [CrossRef]

8. Vazirzadeh, A.; Jalali, S.; Farhadi, A. Antibacterial activity of Oliveria decumbens against Streptococcus iniae in Nile tilapia (Oreochromis niloticus) and its effects on serum and mucosal immunity and antioxidant status. Fish Shellfish Immun. 2019, 94, 407-416. [CrossRef]

9. Santiago, H.M.L.; Espinosa, P.A.; Bermúdez, A.M.C. Uso de antibióticos en la camaronicultura. Rev. Mex. Cienc. Farm. 2009, 40, 22-33. Available online: https://www.redalyc.org/articulo.oa?id=57912963005 (accessed on 20 May 2020).

10. Gracia-Valenzuela, M.H.; Orozco-Medina, C.; Molina-Maldonado, C. Efecto antibacteriano del aceite esencial de orégano (Lippia berlandieri) en bacterias patógenas de camarón Litopenaeus vannamei. Hidrobiológica 2012, 22, 201-206. Available online: http://www.scielo.org.mx/scielo.php?script=sci_arttext\&pid=S018888972012000300002\&lng=es (accessed on 17 May 2020).

11. Nya, E.J.; Austin, B. Use of garlic, Allium sativum, to control Aeromonas hydrophila infection in rainbow trout, Oncorhynchus mykiss (Walbaum). J. Fish Dis. 2009, 32, 963-970. [CrossRef]

12. Tkachenko, H.; Buyun, L.; Terech-Majewska, E.; Osadowski, Z. In vitro antimicrobial activity of ethanolic extracts obtained from Ficus spp. leaves against the fish pathogen Aeromonas hydrophila. Arch. Pol. Fish. 2016, 24, 219-230. [CrossRef]

13. Peretta, A.; Antúnez, K.; Zunino, P. Resistencia a los antimicrobianos en bacterias aeromonadales móviles aisladas de peces cultivados en Uruguay. Veterinaria (Montevideo) 2019, 55, 4-8. Available online: http: //www.scielo.edu.uy/pdf/vet/v55n211/1688-4809-vet-55-211-4.pdf (accessed on 30 April 2020).

14. Akayli, T.; Aydin, B.; Urku, C.; Kayalar, O. Diagnosis of Vibrio anguillarum in culture raibow trout (Oncorhynchus mykiss) by different methods. Eur. J. Biol. 2018, 77, 26-31. [CrossRef]

15. Vásquez-Piñeros, M.; Rondón-Barragán, I.S.; Restrepo-Betancur, L.F.; Eslava-Mocha, P.R. Clinical and hematological study of experimental infection with Aeromonas hydrophila and Edwarsiella tarda on tilapia Oreochromis sp. Orinoquia 2010, 14, 33-44. Available online: http://www.scielo.org.co/scielo.php?script=sci_ arttext\&pid=S0121-37092010000100005\&Ing=en\&tlng=es (accessed on 25 May 2020).

16. Ma, Y.; Yang, M.; Wang, S.; Peng, X. Liver funtional metabolomics discloses an action of l- leucine against Streptococcus iniae infection in tilapias. Fish Shellfish Immun. 2015, 45, 414-421. [CrossRef]

17. Mukwabi, D.M.; Okemo, P.O.; Otieno, S.A.; Oduor, R.O.; Okwany, Z.W. Antibiotic resistant pathogenic bacteria isolated from aquaculture systems in Bungoma County, Kenya. J. Appl. Environ. Microbiol. 2019, 7, 25-37. Available online: http://pubs.sciepub.com/jaem/7/1/5/jaem-7-1-5.pdf (accessed on 20 May 2020).

18. Reverte, M.; Bontemps, N.; Lecchini, D.; Banaigs, B.; Sasal, P. Use of plant extracts in fish aquaculture as an alternative to chemotherapy: Current status and future perspectives. Aquaculture 2014, 433, 50-61. [CrossRef] 
19. Van Hai, N. The use of medicinal plants as immunoestimulants in aquaculture: A review. Aquaculture 2015, 446, 88-96. [CrossRef]

20. U-taynapun, K.; Mueangkan, N.; Chirapongsatonkul, N. Efficacy of herbal extracts to control multi-antibiotics resistant (MAR) Aeromonas veronii isolated from motile Aeromonas septicema (MAS)-Exhibiting Nile tilapia (Oreochromis niloticus). Int. J. Agric. Technol. 2018, 14, 2191-2206. Available online: http://www.ijat-aatsea.com/pdf/ v14_n7_2018_\%20December/108_IJAT_14(7)_2018_Utaynapun,\%20K.pdf (accessed on 30 May 2020).

21. Boran, H.; Çiftci, C.; Er, A.; Köse, Ö.; Tayyip, R. Evaluation of Antibacterial Activity of Green Tea (Camellia sinensis L.) Seeds against Some Fish Pathogens in Rainbow Trout (Oncorhynchus mykiss, Walbaum). Turk. J. Fish. Aquat. Sci. 2015, 15, 49-57. Available online: http://www.trjfas.org/uploads/pdf_7.pdf (accessed on 15 May 2020).

22. Baba, E.; Acar, Ü.; Öntaş, C.; Kesbiç, O.S.; Yilmaz, S. Evaluation of Citrus Limon peles essential oil on growth performance, immune response of Mozanbique tilapia Oreochromis mossambicus challenged with Edwardsiella tarda. Aquaculture 2016, 465, 13-18. [CrossRef]

23. Gültepe, N.; Bilen, S.; Yilmaz, S.; Güroy, D.; Aydm, S. Effects of herbs and spice on health status of tilapia (Oreochromis mossambicus) challenged with Streptococcus iniae. Acta Vet. Brno 2014, 83, 125-131. [CrossRef]

24. Wahab, A.G.; Sallam, A.; Elgaml, A.; Farid, L.M.S.; Afif, M. Antioxidant and antimicrobial activities of Salix babylonica extracts. World J. Pharm. Sci. 2018, 6, 1-6. Available online: https://www.wjpsonline.org/admin/ uploads/Z3D48w.pdf (accessed on 25 May 2020).

25. Popova, T.P.; Kaleva, M.D. Antimicrobial effect in vitro of aqueous extracts of leaves and branches of willow (Salix babylonica L.). Int. J. Curr. Microbiol. Appl. Sci. 2015, 4, 146-152. Available online: https: //www.ijcmas.com/vol-4-10/Teodora\%20P.\%20Popova\%20and\%20Mila\%20D.\%20Kaleva.pdf (accessed on 20 May 2020).

26. Ali, M.R.; Aboud, A.S. Antimicrobial activities of aqueous and methanolic extracts from Salvia officinalis and Salix acmophylla used in the treatment of wound infection isolates. IBN AL-Haitham J. Pure Appl. Sci. 2010, 23, 1-14. Available online: https://www.iasj.net/iasj?func=fulltext\&aId=5132 (accessed on 15 April 2020).

27. González-Alamilla, E.N.; Gonzalez-Cortazar, M.; Valladares-Carranza, B.; Rivas-Jacobo, M.A.; Herrera-Corredor, C.A.; Ojeda-Ramírez, D.; Zaragoza-Bastida, A.; Rivero-Perez, N. Chemical constituents of Salix babylonica L. and their antibacterial activity against Gram-positive and Gram-negative animal bacteria. Molecules 2019, 24, 2992. [CrossRef]

28. González-Alamilla, E.; Rivas-Jacobo, M.; Sosa-Gutiérrez, C.; Delgadillo-Ruiz, L.; Valladares-Carranza, B.; Rosenfeld-Miranada, C.; Zaragoza-Bastida, A.; Rivero-Pérez, N. Efecto antibacteriano del extracto metanolico de Salix babylonica sobre bacterias de importancia en salud pública. Abanico Vet. 2020, 10,1-11. [CrossRef]

29. Clinical and Laboratory Standards Institute. Methods for Dilution Antimicrobial Susceptibility Tests for Bacteria That Grow Aerobically (Approved Standard); CLSI document M7-A5; CLSI: Wayne, PA, USA, 2012.

30. Olmedo-Juarez, A.; Briones-Robles, T.I.; Zaragoza-Bastida, A.; Zamilpa, A.; Ojeda-Ramirez, D.; Mendoza de Gives, P.; Olivares-Perez, J.; Rivero-Perez, N. Antibacterial activity of compounds isolated from Caesalpinia coriaria (Jacq) Willd against important bacteria in public health. Microb. Pathog. 2019, 136, 103660. [CrossRef]

31. Morales-Ubaldo, A.; Hernandez-Alvarado, J.; Valladares-Carranza, B.; Velázquez-Ordoñez, V.; Delgadillo-Ruiz, L.; Rosenfeld-Miranada, C.; Rivero-Pérez, N.; Zaragoza-Bastida, A. Actividad antibacteriana del extracto hidroalcoholico Croton draco sobre bacterias de importancia sanitaria. Abanico Vet. 2020, 10, 1-10. [CrossRef]

32. Turker, H.; Yildirim, A.B.; Karakaş, F.P. Sensitivity of bacteria isolated from fish to some medicinal plants. Turk. J. Fish. Aquat. Sci. 2009, 9, 181-186. Available online: http://www.trjfas.org/uploads/pdf_711.pdf (accessed on 25 May 2020). [CrossRef]

33. Park, Y.K.; Nho, S.W.; Shin, G.W.; Park, S.B.; Jang, H.B.; Cha, I.S.; Ha, M.A.; Kim, Y.R.; Dalvi, R.S.; Kang, B.J.; et al. Antibiotic susceptibility and resistance of Streptococcus iniae and Streptococcus parauberis isolated from olive flounder (Paralechthys olivaceus). Vet. Microbiol. 2009, 136, 76-81. [CrossRef]

34. Altinok, I.; Capkin, E.; Karsi, A. Succinate dehydrogenase mutant of Listonella anguillarum protects rainbow trout against vibriosos. Vaccine 2015, 33, 5572-5577. [CrossRef]

35. Ortega, C.; Valladares, B. Analysis on the development and current situation of rainbow trout (Oncorhynchus mykiss) farming in Mexico. Rev. Aquac. 2015, 9, 194-202. [CrossRef]

36. López-Pueyo, M.J.; Barcenilla-Gaite, F.; Amaya-Villar, R.; Garnacho-Montero, J. Multiresistencia antibiótica en unidades de críticos. Med. Intensiv. 2010, 35, 41-53. Available online: http://scielo.isciii.es/scielo.php? script=sci_arttext\&pid=S0210-56912011000100008\&lng=es (accessed on 30 May 2020). [CrossRef] [PubMed] 
37. Wamala, S.P.; Mugimba, K.K.; Mutoloki, S.; Evensen, Ø.; Mdegela, R.; Byarugaba, D.K.; Sørum, H. Occurrence and antibiotic susceptibility of fish bacteria isolated from Oreochromis niloticus (Nile tilapia) an Clarias gariepinus (African catfish) in Uganda. Fish. Aquat. Sci. 2018, 21, 6. [CrossRef]

38. Negrete, R.P.; Romero, J.J.; Arredondo, F.J.L. Anatibiotic resistance and presence of plasmids in Aeromonas hydrophila, Vibrio fluvialis and Vibrio furnissii isolated from Carassius auratus. Vet. Méx. 2004, 35, 21-30. Available online: http://veterinariamexico.unam.mx/index.php/vet/article/view/100 (accessed on 30 May 2020).

39. Vaseeharan, B.; Lin, J.; Ramasamy, P. Effect of probiotics, antibiotic sensitivity, pathogenicity, and plasmid profiles of Listonella anguillarum-like bacteria isolated from Penaeus monodon culture systems. Aquaculture 2004, 241, 77-91. [CrossRef]

40. Nikapitiya, C.; Chandrarathna, H.P.S.U.; Dananjaya, S.H.S.; De Zoysa, M.; Lee, J. Isolation and characterization of phage (ETP-1) specific to multidrug resistant pathogenic and its in vivo biocontrol efficacy in zebrafish (Danio rerio). Biologicals 2020, 63, 14-23. [CrossRef]

41. Wei, L.S.; Wee, W.; Siong, J.Y.F.; Syamsumir, D.F. Characterization of antimicrobial, antioxidant, anticancer property and chemical composition of Michelia champaca seed and flower extracts. Stamford J. Pharm. Sci. 2011, 4, 19-24. Available online: http://umkeprints.umk.edu.my/234/ (accessed on 1 June 2020). [CrossRef]

42. Bulfon, C.; Volpatti, D.; Galeotti, M. In vitro antibacterial activity of plant ethanolic extracts against fish pathogens. J. World Aquac. Soc. 2014, 45, 545-557. [CrossRef]

43. Abutbul, S.; Golan-Goldhirsh, A.; Barazani, O.; Zilberg, D. Use of Rosmarinus officinalis as a treatment against Streptococcus iniae in tilapia (Oreochromis sp.). Aquaculture 2004, 238, 97-105. [CrossRef]

44. Lee, S.W.; Najiah, M. Antimicrobial property of 2-hydroxypropane-1, 2, 3-tricarboxylic acid isolated from Citrus microcarpa extract. Agric. Sci. China 2009, 8, 880-886. [CrossRef]

45. Roomiani, L.; Soltani, M.; Akhondzadeh, B.A.; Mahmoodi, A.T.; Mirghaed, A.; Yadollahi, F. Evaluation of the chemical composition and in vitro antimicrobial activity of Rosmarinus officinalis, Zatario multiflora, Anethum graveolens and Eucalyptus globulus against Streptococcus iniae; the cause of zoonotic disease in farmed fish. Iran. J. Fish. Sci. 2012, 12, 702-716. Available online: http://hdl.handle.net/1834/11663 (accessed on 27 May 2020).

46. Eze, A.E.; Danga, Y.S.P.; Okoye, F.B.C. Larvicidal activity of the leaf extract of Spondias mombin Linn. (Anacardiaceae) from various solvents against malarial, dengue and filarial vector mosquitoes (Diptera: Culicidae). J. Vector Borne Dis. 2014, 51, 300-306. Available online: http://www.mrcindia.org/journal/issues/ 514300.pdf (accessed on 20 May 2020). [PubMed]

47. Djihane, B.; Wafa, N.; Elkhamssa, S.; Pedro, D.H.J.; Maria, A.E.; Mihoub, Z.M. Chemical constituents of Helichrysum italicum (Roth) G. Don essential oil and their antimicrobial activity against Gram-positive and Gram-negative bacteria, filamentous fungi and Candida albicans. Saudi Pharm. J. 2017, 25, 780-787. [CrossRef] [PubMed]

48. Gligorić, E.; Igić, R.; Suvajdžić, L.; Grujić-Letić, N. Species of the Genus Salix L.: Biochemical Screening and Molecular Docking Approach to Potential Acetylcholinesterase Inhibitors. Appl. Sci. 2019, 9, 1842. [CrossRef]

49. Rivero-Pérez, N.; Hernández-Alvarado, J.L.; Valladares-Carranza, B.; Delgadillo-Ruiz, L.; Ojeda-Ramírez, D.; Sosa-Gutiérrez, C.G.; Morales-Ubaldo, A.L.; Vega-Sánchez, V.; Zaragoza-Bastida, A. Salix babylonica L. as a natural anticoccidial alternative in growing rabbits. Evid.-Based Complement. Altern. Med. 2019, 2019, 1-9. [CrossRef]

50. Rivero, N.; Salem, A.Z.M.; Gado, H.M.; González-Ronquillo, M.; Pliego, A.B.; Peñuelas, C.G.; Odongo, N.E. Effect of exogenous enzymes and Salix babylonica extractr their combination on haematological parameters in growing lambs. J. Anim. Feed Sci. 2012, 21, 577-586. [CrossRef]

C 2020 by the authors. Licensee MDPI, Basel, Switzerland. This article is an open access article distributed under the terms and conditions of the Creative Commons Attribution (CC BY) license (http://creativecommons.org/licenses/by/4.0/). 